\section{FURTHER ADDITIONS TO THE ODONATA (INSECTA) FAUNA OF GOA, INDIA}

\section{Parag Rangnekar ${ }^{1}$ \& Rohan Naik ${ }^{2}$}

${ }^{1}$ Building 4, S-3, Technopark, Chogm Road, Alto-Porvorim, Goa 403001, India ${ }^{2}$ S-1, C-1, Sarthak Garden, Above Powermax Gym, Dhavali-Ponda, Goa 403401, India

1 paragrangnekar@yahoo.com (Corresponding author) ${ }^{2}$ rahutherebel@gmail.com

The first peer reviewed work on the odonate fauna for the State of Goa was by Prasad (1995) wherein 22 species were reported. The Fauna of Goa: State Fauna Series (Kulkarni \& Talmale 2008) by Zoological Survey of India added another 17 species to the list by Prasad, thereby increasing the tally to 39. Rangnekar et al. (2010) further added 34 species to the State list. Recently, Subramanian et al. (2013) described Idionyx gomantakensis, a species new to science collected from Collem, Goa based on samples collected by the authors. Thus, a total of 74 species were so far known from the State. In the present communication we report an additional 13 species from the State of Goa.

The authors surveyed varied habitats in the State of Goa from August 2011 to July 2012, especially forest habitats to document the odonate diversity. The surveyed sites are listed in Table 1.

Individual specimens were photo-documented from various angles and these images were cross-checked with identification manuals for identification (Images 1-13). Collection and killing was avoided for species which could be visually identified. For difficult species, specimens were collected using sweep nets, kept in paper envelopes and then preserved in $70 \%$ alcohol. The collected specimens were identified using standard field guides (Fraser 1933, 1934, 1936; Subramanian 2005). The specimen are maintained with the corresponding author for further investigations and will be deposited in a recognised repository in the future

Of the species documented during the survey, 13 species are new records for the state. Of these, five species are endemic to the Western Ghats. A detailed, systematic account of the species is given below:

\section{Suborder: Anisoptera}

Family: Aeshnidae

\section{Gynacantha dravida Lieftinck, 1960}

Material examined: 1 male, 9.v.2012, coll. Rohan Naik Distribution: Painguinim, Kapileshwari (Canacona)

Comment: The species was observed along forest paths under dense forest canopy with very little sunlight. The species was found active during overcast conditions.

Family: Gomphidae

\section{Gomphidia kodaguensis Fraser, 1923}

Material examined: 1 male, 18.v.2012, coll. Parag Rangnekar

Distribution: Mainapi (Sanguem), Collem and Dabhal (Dharbandhora)

Comments: The species is seen in flight from March to June along forest streams and rivers. This record extends its distribution northwards into the northern Western Ghats.

\footnotetext{
DOI: http://dx.doi.org/10.11609/JoTT.03641.5585-9 | ZooBank: urn:Isid:zoobank.org:pub:B7D366DA-1374-49D4-A673-B9A918FDC14F

Editor: K.A. Subramanian, Zoological Survey of India, Kolkata, India.

Date of publication: 26 March 2014 (online \& print)

Manuscript details: Ms \# 03641 | Received 26 May 2013 | Final received 15 February 2014 | Finally accepted 29 February 2014

Citation: Rangnekar, P. \& R. Naik (2014). Further additions to the Odonata (Insecta) fauna of Goa, India. Journal of Threatened Taxa 6(3): 5585-5589; http://dx.doi. org/10.11609/JoTT.03641.5585-9

Copyright: @ Rangnekar \& Naik 2014. Creative Commons Attribution 3.0 Unported License. JoTT allows unrestricted use of this article in any medium, reproduction and distribution by providing adequate credit to the authors and the source of publication.

Funding: Department of Science, Technology \& Environment, Government of Goa

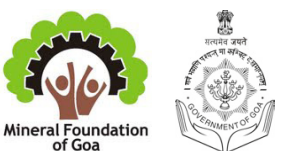

Acknowledgements: We thank the Mineral Foundation of Goa for providing logistic and departmental support and the Department of Science \& Technology, Government of Goa for providing financial support to carry out the study. Thanks are due to the Department of Forests for issuing permission to collect specimen throughout the state (Letter No. 2-WL-Perm/NP-2007-11-FD/5951 dt. 09-01.2012). We acknowledge the guidance provided by Dr. K.A. Subramanian throughout the study period. Special mention of Mr. Sridhar Halali \& Mandar Gaude for assistance during field visits and we also acknowledge the support of all our friends and well-wishers.
} 
Table 1. Survey locations

\begin{tabular}{|c|c|c|c|c|}
\hline & Location & Taluka & District & Habitat \\
\hline 1 & Savari & Sanguem & $\begin{array}{l}\text { South } \\
\text { Goa }\end{array}$ & Perennial hill stream \\
\hline 2 & Ambeghat & Sanguem & $\begin{array}{l}\text { South } \\
\text { Goa }\end{array}$ & $\begin{array}{l}\text { Hill stream with } \\
\text { cascade }\end{array}$ \\
\hline 3 & Collem & Dharbandhora & $\begin{array}{l}\text { South } \\
\text { Goa }\end{array}$ & $\begin{array}{l}\text { Fast flowing, canopy } \\
\text { laden river }\end{array}$ \\
\hline 4 & Vichundrem & Sanguem & $\begin{array}{l}\text { South } \\
\text { Goa }\end{array}$ & $\begin{array}{l}\text { Streams through } \\
\text { paddy fields }\end{array}$ \\
\hline 5 & Jakem & Sanguem & $\begin{array}{l}\text { South } \\
\text { Goa }\end{array}$ & $\begin{array}{l}\text { Streams through } \\
\text { paddy fields }\end{array}$ \\
\hline 6 & Pachmi & Ponda & $\begin{array}{l}\text { North } \\
\text { Goa }\end{array}$ & $\begin{array}{l}\text { Seasonal stagnant } \\
\text { water body at the } \\
\text { base of a hill }\end{array}$ \\
\hline 7 & Karmali & Tiswadi & $\begin{array}{l}\text { North } \\
\text { Goa }\end{array}$ & $\begin{array}{l}\text { Perennial lake and } \\
\text { nearby paddy fields }\end{array}$ \\
\hline 8 & Shivde & Dharbandhora & $\begin{array}{l}\text { South } \\
\text { Goa }\end{array}$ & Hill stream \\
\hline 9 & Nirankal & Ponda & $\begin{array}{l}\text { North } \\
\text { Goa }\end{array}$ & Slow flowing stream \\
\hline 10 & Dapodem & Sanguem & $\begin{array}{l}\text { South } \\
\text { Goa }\end{array}$ & Paddy fields \\
\hline 11 & Mayem & Bicholim & $\begin{array}{l}\text { North } \\
\text { Goa }\end{array}$ & Lake \\
\hline 12 & Dudhsagar & Dharbandhora & $\begin{array}{l}\text { South } \\
\text { Goa }\end{array}$ & $\begin{array}{l}\text { Fast flowing hill } \\
\text { stream }\end{array}$ \\
\hline 13 & Sacorda & Dharbandhora & $\begin{array}{l}\text { South } \\
\text { Goa }\end{array}$ & Hill stream \\
\hline 14 & Hivre & Sattari & $\begin{array}{l}\text { North } \\
\text { Goa }\end{array}$ & Hill stream \\
\hline 15 & Charavane & Sattari & $\begin{array}{l}\text { North } \\
\text { Goa }\end{array}$ & Hill stream \\
\hline 16 & Tambdi-Surla & Dharbandhora & $\begin{array}{l}\text { South } \\
\text { Goa }\end{array}$ & Hill stream \\
\hline 17 & Barabhoomi & Dharbandhora & $\begin{array}{l}\text { South } \\
\text { Goa }\end{array}$ & Hill stream \\
\hline 18 & Vante & Sattari & $\begin{array}{l}\text { North } \\
\text { Goa }\end{array}$ & River \\
\hline 19 & Vaiguinim & Sattari & $\begin{array}{l}\text { North } \\
\text { Goa }\end{array}$ & Hill stream \\
\hline 20 & Panshi & Dharbandhora & $\begin{array}{l}\text { South } \\
\text { Goa }\end{array}$ & River \\
\hline 21 & Curtorim & Salcette & $\begin{array}{l}\text { South } \\
\text { Goa }\end{array}$ & Lake \\
\hline
\end{tabular}

\section{Merogomphus longistigma (Fraser, 1922)}

Material examined: 1 male, 1 female, 23.ix.2011, coll. Parag Rangnekar \& Rohan Naik

Distribution: Vichundre (Sanguem)

Comments: The species was observed during the monsoons. The species has a habit of perching on low vegetation along streams. This record extends its distribution northwards into the northern Western Ghats.

\section{Megalogomphus hannyngtoni (Fraser, 1923)}

Material examined: None. Sighted on 18.v.2012

Distribution: Mainapi (Sanguem)

Comment: The individual was identified based on images from various angles since efforts to collect a

\begin{tabular}{|c|c|c|c|c|}
\hline & Location & Taluka & District & Habitat \\
\hline 22 & Raitale & Salcette & $\begin{array}{l}\text { South } \\
\text { Goa }\end{array}$ & Lake \\
\hline 23 & Pernem & Pernem & $\begin{array}{l}\text { North } \\
\text { Goa }\end{array}$ & $\begin{array}{l}\text { Stream with } \\
\text { adjoining paddy } \\
\text { fields }\end{array}$ \\
\hline 24 & Madkai & Ponda & $\begin{array}{l}\text { North } \\
\text { Goa }\end{array}$ & Lake \\
\hline 25 & Kaskond & Dharbandhora & $\begin{array}{l}\text { South } \\
\text { Goa }\end{array}$ & Hill stream \\
\hline 26 & Satpal & Dharbandhora & $\begin{array}{l}\text { South } \\
\text { Goa }\end{array}$ & Hill streams \\
\hline 27 & Fulamol & Canacona & $\begin{array}{l}\text { South } \\
\text { Goa }\end{array}$ & Hill stream \\
\hline 28 & Dabhel & Canacona & $\begin{array}{l}\text { South } \\
\text { Goa }\end{array}$ & Hill stream \\
\hline 29 & Painguinim & Canacona & $\begin{array}{l}\text { South } \\
\text { Goa }\end{array}$ & $\begin{array}{l}\text { Stream with paddy } \\
\text { fields }\end{array}$ \\
\hline 30 & Sonauli & Dharbandhora & $\begin{array}{l}\text { South } \\
\text { Goa }\end{array}$ & Hill stream \\
\hline 31 & Mainapi & Sanguem & $\begin{array}{l}\text { South } \\
\text { Goa }\end{array}$ & Hill stream \\
\hline 32 & Ponsuli & Sanguem & $\begin{array}{l}\text { South } \\
\text { Goa }\end{array}$ & Hill stream \\
\hline 33 & Ganjem & Ponda & $\begin{array}{l}\text { North } \\
\text { Goa }\end{array}$ & River \\
\hline 34 & Opa & Ponda & $\begin{array}{l}\text { North } \\
\text { Goa }\end{array}$ & River \\
\hline 35 & Kodar & Ponda & $\begin{array}{l}\text { North } \\
\text { Goa }\end{array}$ & River \\
\hline 36 & Keri & Ponda & $\begin{array}{l}\text { North } \\
\text { Goa }\end{array}$ & Hill stream \\
\hline 37 & Bhironda & Sattari & $\begin{array}{l}\text { North } \\
\text { Goa }\end{array}$ & River \\
\hline 38 & Macazana & Salcette & $\begin{array}{l}\text { South } \\
\text { Goa }\end{array}$ & Lake \\
\hline 39 & Kapileshwari & Ponda & $\begin{array}{l}\text { North } \\
\text { Goa }\end{array}$ & $\begin{array}{l}\text { Stream with paddy } \\
\text { fields }\end{array}$ \\
\hline 40 & Mapusa & Bardez & $\begin{array}{l}\text { North } \\
\text { Goa }\end{array}$ & Stagnant drains \\
\hline 41 & Tulshimol & Canacona & $\begin{array}{l}\text { South } \\
\text { Goa }\end{array}$ & Pond \\
\hline
\end{tabular}

specimen were in vain. The species is seen in flight from March to June along forest streams and rivers. This record extends its distribution northwards into the northern Western Ghats.

Family: Libellulidae

\section{Onychothemis testacea (Ris, 1912)}

Material examined: 1 male, 11.v.2012, coll. Parag Rangnekar \& Rohan Naik

Distribution: Sonauli (Dharbandhora)

Comments: The species was observed during the summer season in the month of March along forest streams and rivers. The species does not prefer open areas like the Gomphids and keeps to shady places in the river with overhanging vegetation, where a number of 
individuals of both sexes can be sighted.

\section{Urothemis signata (Rambur, 1842)}

Material examined: None

Distribution: Karmali (Tiswadi), Mapusa (Bardez), Curtorim (Salcette)

Comment: The individuals were identified based on images and hence collection was not necessary. This species prefers open tanks and lakes with reed-beds.

\section{Zygonyx iris malabarica Fraser, 1926}

Material examined: 1 male, 11.v.2012, coll. Parag Rangnekar \& Rohan Naik

Distribution: Doodhsagar, Collem (Dharbandhora), Mainapi (Sanguem)

Comments: The species is seen hovering along forest streams. Very rarely can one see an individual perched. The species can be easily identified in flight by the metallic colours and the characteristic yellowish spot on the $7^{\text {th }}$ abdominal segment.

\section{Family: Macromiidae}

\section{Epophthalmia vittata Burmeister, 1839}

Material examined: 1 male, 4.x.2011, coll. Rohan Naik Distribution: Karmali (Tiswadi), Curtorim (Salcette), Satpal (Dharbandhora), Collem (Sanguem) Comments: The species is a strong flier and is seen patrolling along the banks of large water tanks and lakes. The species is sighted in forest habitats as well. Very rarely can one sight an individual perched.

\section{Suborder: Zygoptera}

Family: Coenagrionidae

\section{Archibasis oscillans (Selys, 1877)}

Material examined: 1 male, 10.v.2012, coll. Rohan Naik

Distribution: Paiguinim (Canacona)

Comments: The species was sighted among the reeds around water tanks. The pale body color and the shape of the pterostigma separate it from other genus of the Marsh Darts such as Pseudagrion.

\section{Ceriagrion rubiae Laidlaw, 1916}

Material examined: 1 male, 2.ii.2012, coll. Rohan Naik Distribution: Panshi (Ponda), Satpal (Dharbandhora)

Comments: This species was sighted in a variety of habitats, especially near the ephemeral lateritic pools.

\section{Pseudagrion rubriceps Selys, $\mathbf{1 8 7 6}$}

Material examined: 1 male, 1 female, 24.i.2012, coll. Rohan Naik
Distribution: Mhadei (Sattari), Ganje (Ponda), Dabhal (Dharbandhora), Satpal (Dharbandhora), Pernem

Comments: The species was sighted along streams and rivers mostly in groups.

Family: Platystictidae

12. Protosticta sanguinostigma Fraser, 1922

Material examined: Four males, 25.iv.2012, 9.v.2012, 11.v.2012, 28.v.2012, coll. Parag Rangnekar, Rohan Naik \& Shridhar Halali

Distribution: Collem, Dabhal (Dharbandhora), Mainapi, Savari (Sanguem)

Comments: The species can be differentiated from other of its genus by its blood-red pterostigma. The species is in flight from the beginning of the monsoons till the end of the monsoons after which the sightings seem to decrease. This record extends its distribution northwards into the northern Western Ghats.

\section{Family: Protoneuridae}

\section{Caconeura ramburi (Fraser, 1922)}

Material examined: 2 males, 28.v.2012, coll. Parag Rangnekar

Distribution: Collem (Dharbandhora), Mainapi (Sanguem)

Comments: The species is best sighted along small hill streams with good forest cover. The species is sighted during pre-monsoons and more commonly during the monsoons.

\section{Discussion}

With the addition of 13 new records for the State, the tally of odonate diversity stands at 87 . Of these five are endemic to the Western Ghats. The study also adds one family Macromiidae not reported earlier from the State. Compared to the known diversity of Odonates from Peninsular India, which is around 200, the present species count is surely an underestimate. We strongly believe that sustained and co-ordinated efforts are necessary for documenting the odonate diversity of the state. This is possible through networking between the government and researchers for which the department of forest can act as the nodal agency. Further, since odonates are indicator species, it is necessary that other than diversity, abundance studies and long-term monitoring need to be taken up for major water bodies in the state.

\section{References}

Fraser, F.C. (1933). The Fauna of British India including Ceylon and Burma. Odonata Vol. I. Taylor and Francis Ltd., London, 423pp Fraser, F.C. (1934). The Fauna of British India including Ceylon and 


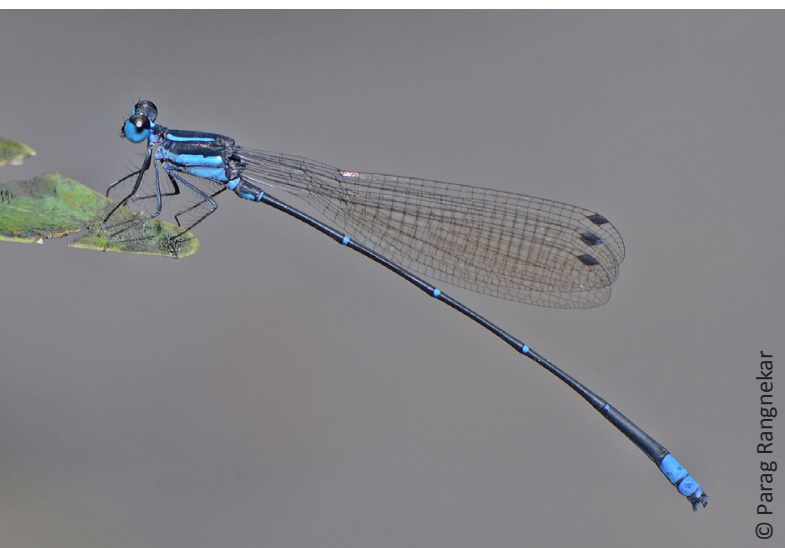

Image 1. Caconeura ramburi

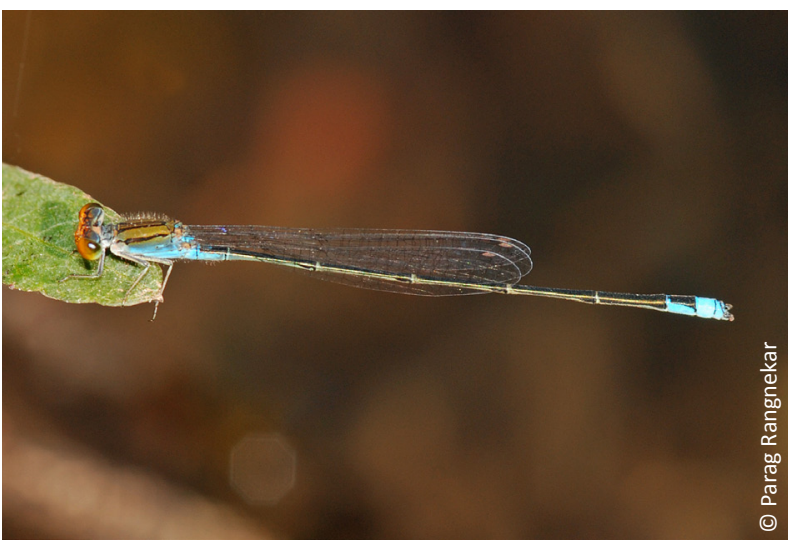

Image 3. Pseudagrion rubriceps

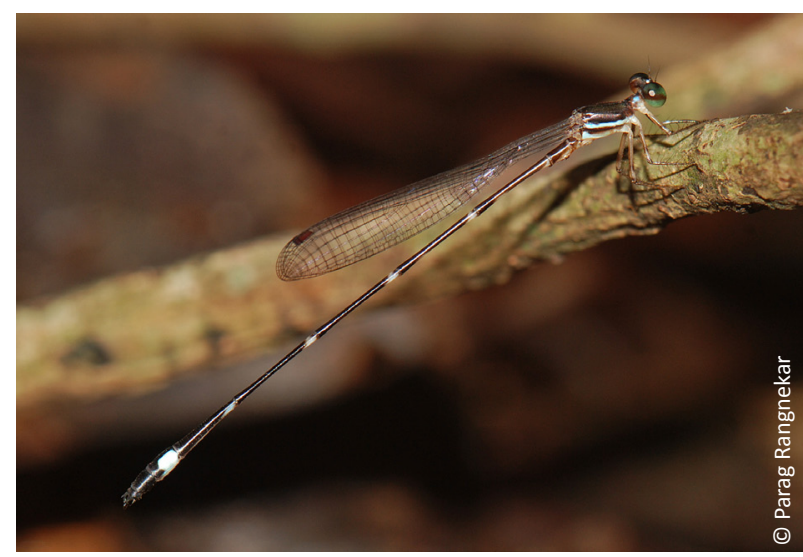

Image 5. Protosticta sanguinostigma - Male

Burma. Odonata Vol. II. Taylor and Francis Ltd., London, 398pp Fraser, F.C. (1936). The Fauna of British India including Ceylon and Burma. Odonata Vol. III. Taylor and Francis Ltd., London, 461pp Kulkarni P.P. \& S.S. Talmale (2008). Insecta: Odonata. Fauna of Goa, State Fauna Series, Zoological Survey of India 16: 173-194 Prasad, M. (1995). On a collection of odonata from Goa. Fraseria (N.S.) 2(1/2): 7-8.

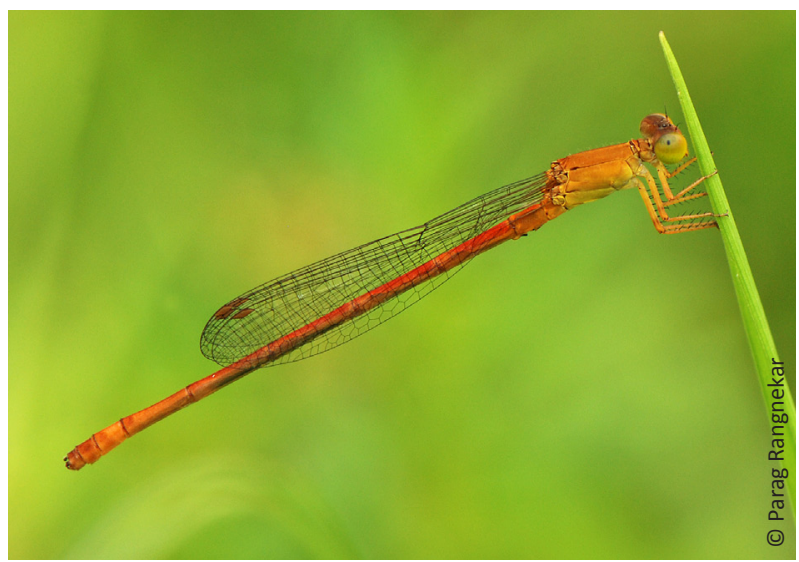

Image 2. Ceriagrion rubiae

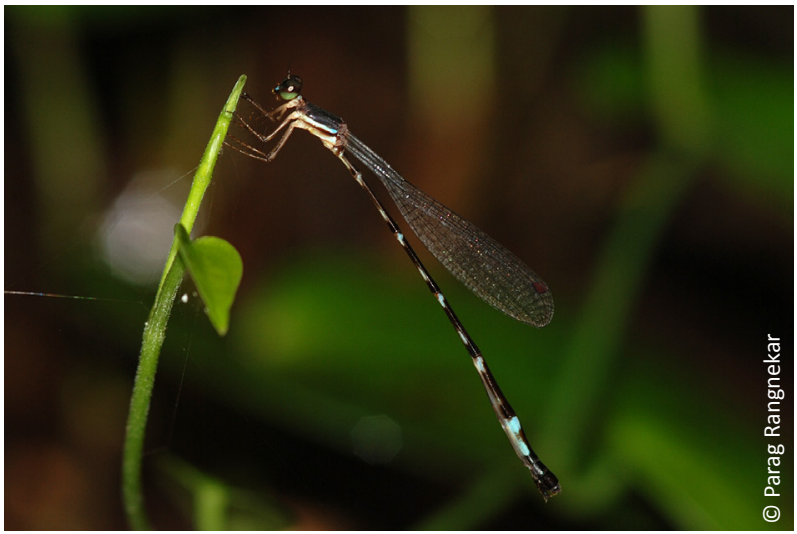

Image 4. Protosticta sanguinostigma - Female

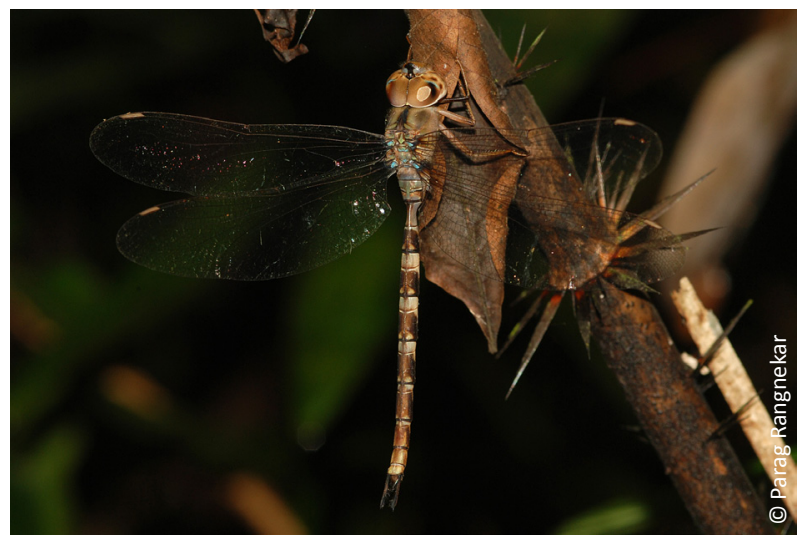

Image 6. Gynacantha dravida

Rangnekar P., M. Borkar \& O. Dharwadkar (2010). Additions to the Odonata (Insecta) of Goa. Journal of Threatened Taxa 2(4): 805814; http://dx.doi.org/10.11609/JoTT.o2286.805-14

Subramanian, K.A. (2005). Dragonflies and Damselflies of Peninsular India - A Field Guide-1st Edition. Madhav Gadgil. Published under the Project Lifescape Series. Indian Academy of Sciences, Banglore, $118 p$. 


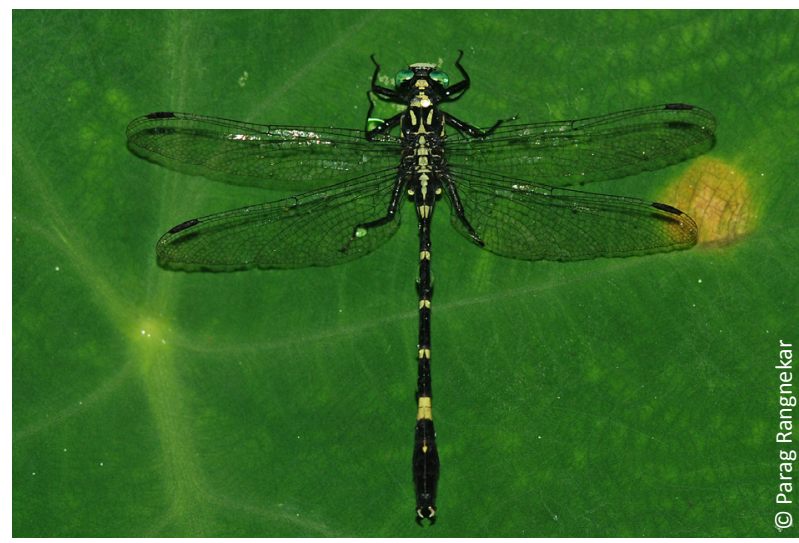

Image 7. Merogomphus longistigma

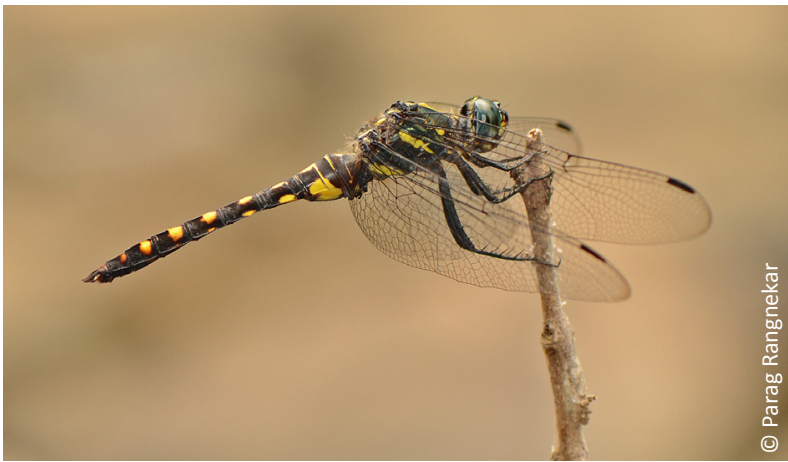

Image 9. Onycothemis testacea

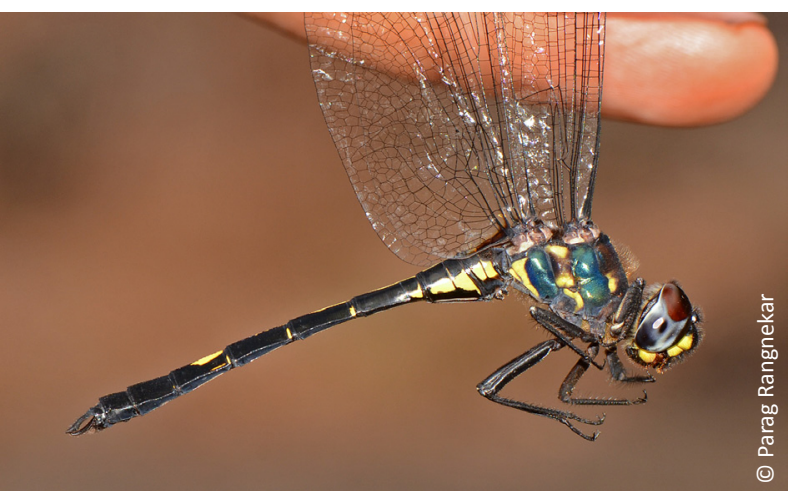

Image 11. Zygonix iris

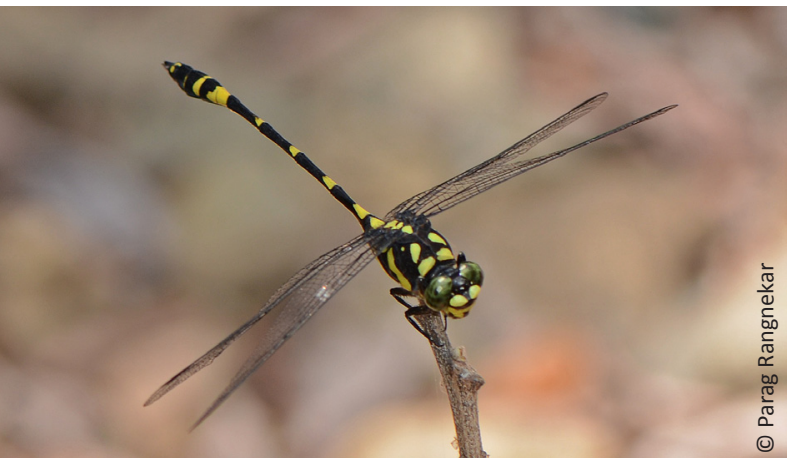

Image 13. Gomphidia koduguensis

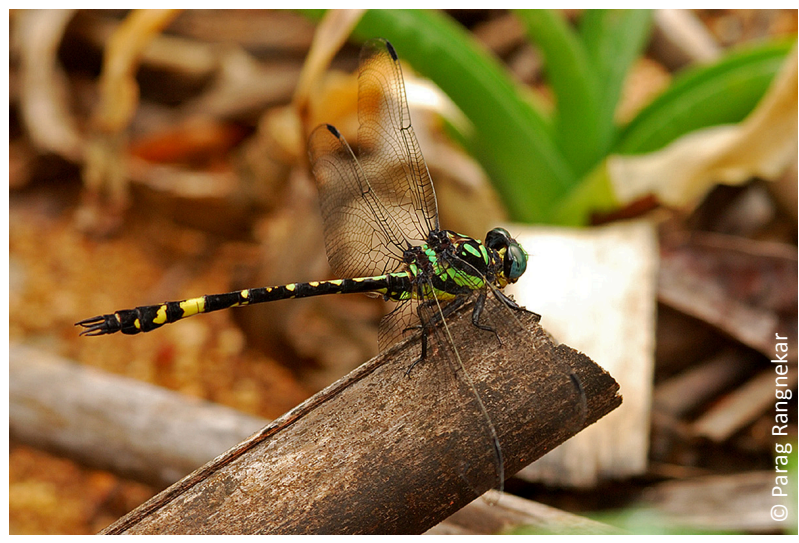

Image 8. Megalogomphus hanningtonii

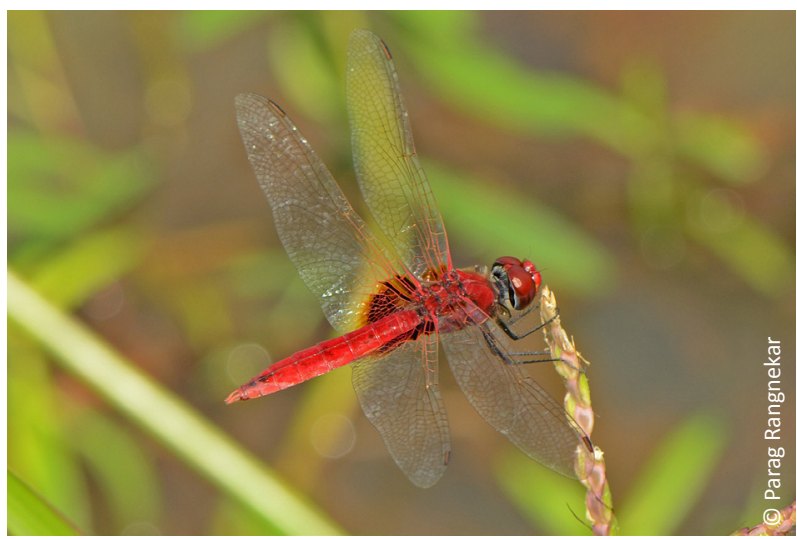

Image 10. Urothemis signato

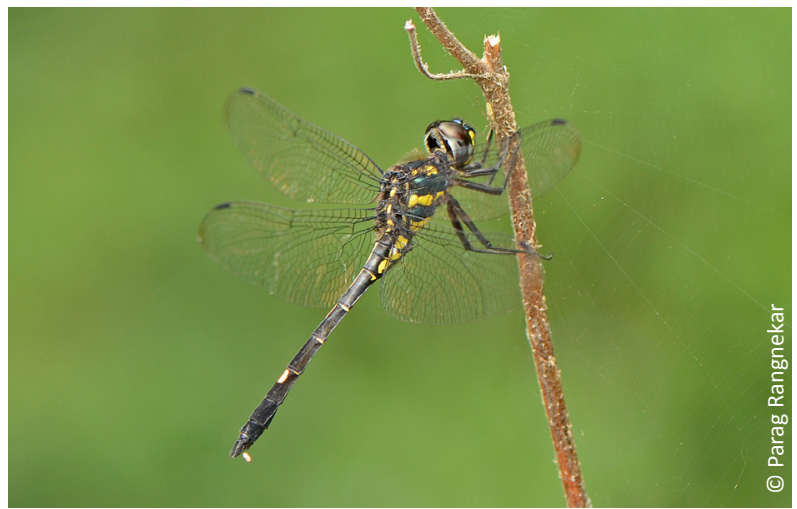

Image 11. Zygonix iris

Subramanian K.A., P. Rangnekar \& R. Naik (2013). Idionyx (Odonata: Corduliidae) of the Western Ghats with a description of a new species. Zootaxa 3652(2): 277-288.

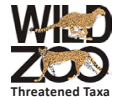

